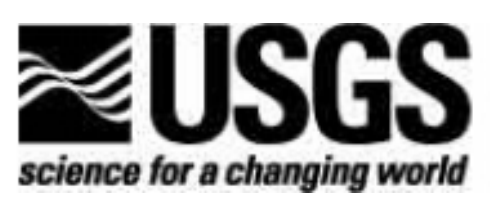

\title{
Coastal Vulnerability Assessment of Gateway National Recreation Area (GATE) to Sea-Level Rise
}

By Elizabeth A. Pendleton, E. Robert Thieler, and S. Jeffress Williams

Any use of trade, firm, or product names is for descriptive purposes only and does not imply endorsement by the U.S. Government

\section{Open-File Report 2004-1257}

2005

U.S. Department of the Interior U.S. Geological Survey 


\title{
U.S. Department of the Interior
}

\author{
Gale A. Norton, Secretary
}

\section{U.S. Geological Survey \\ Charles G. Groat, Director}

\section{U.S. Geological Survey, Reston, Virginia \\ For Additional Information: \\ See the National Park Unit Coastal Vulnerability study at http://woodshole.er.usgs.gov/project-pages/nps-cvi/, the National Coastal Vulnerability study at http://woodshole.er.usgs.gov/project-pages/cvi/, or view the USGS online fact sheet for this project in PDF format at http://pubs.usgs.gov/fs/fs095-02/. To visit Virgin Islands Natinal Park Web sitego to http://www.nps.gov/gate/index.htm.}

Contact:

http://woodshole.er.usgs.gov/project-pages/nps-cvi/ Telephone: 508-548-8700

Rebecca Beavers

National Park Service

Natural Resource Program Center

Geologic Resources Division

P.0. Box 25287

Denver, CO 80225-0287

Rebecca_Beavers@nps.gov

Telephone: 303-987-6945

For more information on the USGS - the Federal source for science about the Earth, its natural and living resources, natural hazards, and the environment:

World Wide Web: http://www.usgs.gov

Telephone: 1-888-ASK-USGS

Although this report is in the public domain, permission must be secured from the individual copyright owners to reproduce any copyrighted material contained within this report. 


\section{Contents}

Abstract $\ldots \ldots$
Introduction
Data Ranking
The Gateway




\title{
Coastal Vulnerability Assessment of Gateway National Recreation Area (GATE) to Sea-Level Rise
}

\author{
By Elizabeth A. Pendleton, E. Robert Thieler, S. and Jeffress Williams
}

\begin{abstract}
A coastal vulnerability index (CVI) was used to map the relative vulnerability of the coast to future sealevel rise within Gateway National Recreation Area in New York and New Jersey. The CVI ranks the following in terms of their physical contribution to sea-level rise-related coastal change: geomorphology, regional coastal slope, rate of relative sea-level rise, historical shoreline change rates, mean tidal range, and mean significant wave height. The rankings for each variable were combined and an index value was calculated for 1-minute grid cells covering the park. The CVI highlights those regions where the physical effects of sea-level rise might be the greatest. This approach combines the coastal system's susceptibility to change with its natural ability to adapt to changing environmental conditions, yielding a quantitative, although relative, measure of the park's natural vulnerability to the effects of sea-level rise. The CVI provides an objective technique for evaluation and long-term planning by scientists and park managers. Gateway National Recreation Area consists of stable and washover dominated segments of Holocene barrier spit on Breezy Point and Sandy Hook, and Pleistocene glacial outwash and historic artificial fill on Staten Island. The areas within Gateway that are likely to be most vulnerable to sea-level rise are those with the highest occurrence of overwash and the highest rates of shoreline change.
\end{abstract}

\section{Introduction}

The National Park Service (NPS) is responsible for managing nearly 12,000 km (7,500 miles) of shoreline along oceans and lakes. In 2001, the U.S. Geological Survey (USGS), in partnership with the NPS Geologic Resources Division, began conducting hazard assessments of future sea-level change by creating maps to assist NPS in managing its valuable coastal resources. This report presents the results of a vulnerability assessment for Gateway National Recreation Area, highlighting areas that are likely to be most affected by future sea-level rise.

Global sea level has risen approximately 18 centimeters (7.1 inches) in the past century (Douglas, 1997). Climate models predict an additional rise of $48 \mathrm{~cm}$ (18.9 inches) by 2100 (IPCC, 2001), which is more than double the rate of rise for the 20th century. Potential coastal impacts of sea-level rise include shoreline erosion, saltwater intrusion into groundwater aquifers, inundation of wetlands and estuaries, and threats to cultural and historic resources as well as infrastructure. Predicted accelerated global sea-level rise has generated a need in coastal geological studies to determine the likely response of a coastline to sea-level rise. However, an accurate and quantitative approach to predicting coastal change is difficult to establish. Even the kinds of data necessary to predict shoreline response are the subject of scientific debate. A number of predictive approaches have been proposed (National Research Council, 1990 and 1995), including:

1. extrapolation of historical data (e.g., coastal erosion rates),

2. static inundation modeling,

3. application of a simple geometric model (e.g., the Bruun Rule),

4. application of a sediment dynamics/budget model, or

5. Monte Carlo (probabilistic) simulation based on parameterized physical forcing variables. 
However, each of these approaches has inadequacies or can be invalid for certain applications (National Research Council, 1990). Additionally, shoreline response to sea-level change is further complicated by human modification of the natural coast such as beach nourishment projects, and engineered structures such as seawalls, revetments, groins, and jetties. Understanding how a natural or modified coast will respond to sea-level change is essential to preserving vulnerable coastal resources.

The primary challenge in predicting shoreline response to sea-level rise is quantifying the important variables that contribute to coastal evolution in a given area. In order to address the multi-faceted task of predicting sea-level rise impact, the USGS has implemented a methodology to identify areas that may be most vulnerable to future sea-level rise (see Hammar-Klose and Thieler, 2001). This technique uses different ranges of vulnerability (low to very high) to describe a coast's susceptibility to physical change as sea level rises. The vulnerability index determined here focuses on six variables that strongly influence coastal evolution:

1. Geomorphology

2. Historical shoreline change rate

3. Regional coastal slope

4. Relative sea-level change

5. Mean significant wave height

6. Mean tidal range

These variables can be divided into two groups: 1) geologic variables and 2) physical process variables. The geologic variables are geomorphology, historic shoreline change rate, and coastal slope; they account for a shoreline's relative resistance to erosion, long-term erosion/accretion trend, and its susceptibility to flooding, respectively. The physical process variables include significant wave height, tidal range, and sea-level change, all of which contribute to the inundation hazards of a particular section of coastline over time scales from hours to centuries. A relatively simple vulnerability ranking system (Table 1) allows the six variables to be incorporated into an equation that produces a coastal vulnerability index (CVI). The CVI can be used by scientists and park managers to evaluate the likelihood that physical change may occur along a shoreline as sea level continues to rise.

Additionally, NPS staff will be able to incorporate information provided by this vulnerability assessment technique into general management plans.

\section{Data Ranking}

Table 1 shows the six variables described in the Introduction, which include both quantitative and qualitative information. Numeric variable values are assigned a vulnerability ranking based on value ranges, whereas the non-numerical geomorphology variable is ranked qualitatively according to the relative resistance of a given landform to erosion. Shorelines with historical erosion/accretion rates between -1.0 and $+1.0 \mathrm{~m} / \mathrm{yr}$ are ranked as moderate. Increasingly higher erosion or accretion rates are ranked as correspondingly higher or lower vulnerability. Regional coastal slopes range from very high risk, $<0.3$ percent to very low risk at values $>1.2$ percent. The rate of relative sea-level change is ranked using the modern rate of eustatic rise $(1.8 \mathrm{~mm} / \mathrm{yr})$ as very low vulnerability. Since this is a global or "background" rate common to all shorelines, the sea-level rise ranking reflects primarily local to regional isostatic or tectonic adjustment. Mean wave height rankings range from very low $(<0.55 \mathrm{~m})$ to very high $(>1.25 \mathrm{~m})$. Tidal range is ranked such that microtidal $(<1 \mathrm{~m})$ coasts are very high vulnerability and macrotidal $(>6 \mathrm{~m})$ coasts are very low vulnerability..

\section{The Gateway National Recreation Area}

Gateway National Recreation Area (GATE) is broken into 3 units, Staten Island, Jamaica Bay, and Sandy Hook, along the metropolitan shoreline of New York and New Jersey (Figure 1). This National Recreation Area consists of over $45 \mathrm{~km}$ ( 28 miles) of open to near open-ocean shoreline at the entrance of New York Harbor, as well as $40 \mathrm{~km}^{2}(10,000$ acre $)$ of saltmarsh estuary within Jamaica Bay. This report will focus on the three park areas 
considered open-ocean: Sandy Hook and Staten Island Units, and the Breezy Point District of Jamaica Bay Unit. The remainder of the Jamaica Bay Unit consists of saltmarsh and tidal creeks and is not well suited for this project.

\section{The Breezy Point District}

The Breezy Point District lies within the Jamaica Bay Unit on the western end of Rockaway Peninsula (Figure 1). Together Breezy Point and Sandy Hook produce the 'gates' to New York Harbor, thus becoming know as the 'Gateway to Freedom' to many immigrants arriving in the New World. Rockaway Peninsula and the other barriers of Long Island's South Shore began forming seaward of their present location about 8,000 years ago as glacial-fluvial sediments were reworked by waves and currents. Historically, Rockaway built westward in response to the dominant longshore transport current until the jetty at Breezy Point, installed in the 1930s, prevented further progradation to the west. Fort Tilden and Jacob Riis Park are two cultural and recreational attractions within the Breezy Point District.

\section{Staten Island Unit}

The Staten Island Unit lies on the southeast side of Staten Island and faces into Lower New York Bay (Figure 1). A terminal moraine of the Laurentide icesheet passes across Staten Island, and controls the coastal geology for this area (Figure 2). Fronting the moraine are outwash sands and gravels, which comprise the majority of the National Recreation Area (NRA) on Staten Island. However, Great Kills Park lies on top of historic artificial fill, and a portion of Fort Wadsworth is built upon the terminal moraine. Two islands that lie offshore of Staten Island, Hoffman and Swinburne Islands are also part of the NRA and are closed to the public for bird nesting. These islands were constructed and used as a quarantine and crematorium for immigrants in the late $1800 \mathrm{~s}$.

\section{Sandy Hook Unit}

The Sandy Hook Unit lies to the east of the New Jersey Highlands region and is separated from the mainland by Sandy Hook Bay (Figure 1). Similar to Rockaway, Sandy Hook owes its existence to the slow steady rise in sea level throughout the Holocene. The dominant southeast waves within the New York Bight produce a south to north longshore transport of sand along Sandy Hook, resulting in a net accumulation of sand at the north end of Sandy Hook. At present a sand spit, Sandy Hook has been an island a number of times in the past, and is extremely susceptible to storm overwash and breaching at its southern end. Important resources on Sandy Hook include a maritime Holly forest, historic Fort Hancock, and the oldest lighthouse still in operation in the US, Sandy Hook Light.

\section{Jamaica Bay Unit}

The Jamaica Bay Unit includes the Rockaway Peninsula (described above in the Breezy Point District) and saltmarsh and tidal creeks of Jamaica Bay, which are connected to the open ocean by Rockaway Inlet (Figure 1). Jamaica Bay suffered a nearly 50 percent loss of wetland area as a result of development during the late 1800s and early 1900s before the ecologic importance of saltmarsh estuaries was recognized. During the 1930's measures were taken to protect the bay, and in 1972 Gateway NRA was established. A primary objective of the park since its establishment has been to protect the natural resources within Jamaica Bay. However, despite efforts to preserve the critical ecosystem, Jamaica Bay continues to face wetland loss, no longer as a result of landfilling, and development, but more from sea-level rise and secondary anthropogenic effects such as sediment starvation due to the Breezy Point jetty (Hartig and others, 2002).

This report does not directly address the vulnerability of Jamaica Bay to future sea-level rise, because the methodology presented here does not apply well to quiet water wetland environments; however, the authors acknowledge the important issues impacting Jamaica Bay and direct interested readers to comprehensive investigations on sea-level rise and anthropogenic activities in Jamaica Bay: http://www.giss.nasa.gov/research/intro/hartig_01/ (Gornitz and others, 2001; Hartig and others, 2001, 2002) 


\section{Methodology}

In order to develop a database for a park-wide assessment of coastal vulnerability, data for each of the six variables mentioned above were gathered from state and federal agencies (Table 2). The database is based on that used by Thieler and Hammar-Klose (1999) and loosely follows an earlier database developed by Gornitz and White (1992). A comparable assessment of the sensitivity of the Canadian coast to sea-level rise is presented by Shaw and others (1998).

The database was constructed using a 1:70,000-scale shoreline for Gateway that was produced from the medium resolution digital vector U.S. shoreline provided by the Strategic Environmental Assessments Division of the National Oceanic and Atmospheric Administration's Office of Ocean Resources Conservation and Assessment (http://spo.nos.noaa.gov/projects/shoreline/shoreline.html). Data for each of the six variables (geomorphology, shoreline change, coastal slope, relative sea-level rise, significant wave height, and tidal range) were added to the shoreline attribute table using a 1-minute (approximately $1.5 \mathrm{~km}$ ) grid (Figure 3). Next each variable in each grid cell were assigned a relative vulnerability value from 1-5 (1 is very low vulnerability, 5 is very high vulnerability) based on the potential magnitude of its contribution to physical changes on the coast as sea level rises (Table 1).

\section{Geologic Variables}

The geomorphology variable expresses the relative erodibility of different landform types (Table 1). These data were derived from orthophotographs (1994-2002) of Gateway NRA from NY and NJ (Table 2). In addition, field visits were made within the park to verify the geomorphologic classifications. The geomorphology of Gateway varies from very high vulnerability barrier spit and historic artificial fill to moderate vulnerability reworked glacialfluvial deposits. Breezy Point and Sandy Hook were classified as very high vulnerability barrier spit geomorphology (Figure 4A-B). The Staten Island park shoreline varied from very high vulnerability artificial fill at Great Kills Park to moderate vulnerability terminal moraine at Fort Wadsworth (Figure 2 and Figure 5A-C).

Shoreline erosion and accretion rates for Gateway were calculated from existing shoreline data provided by USGS, New York State Department of State (Table 2). Shoreline rates of change (m/yr) were calculated at $200 \mathrm{~m}$ intervals (transects) along the coast using Digital Shoreline Analysis System software (http://woodshole.er.usgs.gov/project-pags/dsas/) to derive the rate of shoreline change over time. The rates for each transect within a 1-minute grid cell were averaged to determine the shoreline change value used here, with positive numbers indicating accretion and negative numbers indicating erosion. Shoreline change rates on Gateway range from greater than $2 \mathrm{~m} / \mathrm{yr}$ of accretion (very low vulnerability) to greater than $2 \mathrm{~m} / \mathrm{yr}$ of erosion (very high vulnerability) (Figure 6A-E).

The determination of regional coastal slope identifies the relative vulnerability of inundation and the potential rapidity of shoreline retreat because low-sloping coastal regions should retreat faster than steeper regions (Pilkey and Davis, 1987). The regional slope of the coastal zone was calculated from a grid of topographic and bathymetric elevations extending $10 \mathrm{~km}$ landward and seaward of the present-day shoreline. Elevation data were obtained from the National Geophysical Data Center (NGDC) as gridded topographic and bathymetric elevations at 0.1 meter vertical resolution for 3 arc-second $(\sim 90 \mathrm{~m})$ grid cells. Regional coastal slopes for Gateway fall within the high vulnerability (4) to very high vulnerability (5) category (Table 1 ).

\section{Physical Process Variables}

The relative sea-level change variable is derived from the increase or decrease in annual mean water elevation over time as measured at tide gage stations along the coast. The rate of sea-level rise at the Battery, NY is $2.77+/-0.05 \mathrm{~mm} / \mathrm{yr}$ based on 144 years of data (Zervas, 2001), and the rate of sea-level rise in Sandy Hook, NJ is $3.88+/-0.15 \mathrm{~mm} / \mathrm{yr}$ based on 68 years of data. This variable inherently includes both global sea-level rise as well as regional sea-level rise due to isostatic and tectonic adjustments of the land surface. Relative sea-level change data are a historical record, and thus only portray the recent sea-level trend ( $<50$ years). The rate of relative sea-level rise for Gateway is moderate (3) in the NY units, and very high (5) in NJ (Table 1). 
Mean significant wave height is used here as a proxy for wave energy which drives the coastal sediment budget. Wave energy is directly related to the square of wave height;

$$
E=1 / 8 \rho g H^{2}
$$

where $E$ is energy density, $H$ is wave height, $\rho$ is water density and $g$ is acceleration due to gravity. Thus, the ability to mobilize and transport coastal sediments is a function of wave height squared. In this report, we use hindcast nearshore mean significant wave height data for the period 1976-95 obtained from the U.S. Army Corps of Engineers Wave Information Study (WIS) (see references in Hubertz and others, 1996). The model wave heights were compared to historical measured wave height data obtained from the NOAA National Data Buoy Center to ensure that model values were representative of the study area. For Gateway, mean significant wave heights are between 1.2 and $1.3 \mathrm{~m}$, which is categorized as high (4) and very high vulnerability (5), respectively (Table 1).

Tidal range is linked to both permanent and episodic inundation hazards. Tide range data were obtained from NOAA/NOS for ocean tide gauges at Fort Wadsworth, Staten Island and Fort Hancock, Sandy Hook. All of Gateway is classified as high vulnerability $(1-2 \mathrm{~m})$ with respect to tidal range (Table 1$)$.

\section{Coastal Vulnerability Index}

The coastal vulnerability index presented here is the same as that used in Thieler and Hammar-Klose (1999) and is similar to that used in Gornitz and others (1994), as well as to the sensitivity index employed by Shaw and others (1998). The CVI allows the six variables to be related in a quantifiable manner that expresses the relative vulnerability of the coast to physical changes due to future sea-level rise. This method yields numerical data that cannot be equated directly with particular physical effects. It does, however, highlight areas where the various effects of sea-level rise may be the greatest. Once each section of coastline is assigned a vulnerability value for each specific data variable, the coastal vulnerability index is calculated as the square root of the product of the ranked variables divided by the total number of variables;

$$
\mathrm{CVI}=\sqrt{\frac{\left(a^{*} b^{*} c^{*} d^{*} e^{*} f\right)}{6}}
$$

where, $\mathrm{a}=$ geomorphology, $\mathrm{b}=$ shoreline erosion/accretion rate, $\mathrm{c}=$ coastal slope, $\mathrm{d}=$ relative sea-level rise rate, $\mathrm{e}=$ mean significant wave height, and $\mathrm{f}=$ mean tide range. The calculated CVI value is then divided into quartile ranges to highlight different vulnerabilities within the park. The numeric CVI values that correspond to a specific vulnerability index (low - very high) are unique to Gateway National Recreation Area, and are not comparable to CVI ranges in other parks where the CVI has been employed (i.e., very high vulnerability means the same among parks; it's the numeric values that differ, such that a numeric value that equals very high vulnerability in one park may equal moderate vulnerability in another). To compare vulnerability among coastal parks, the national-scale studies should be used (Thieler and Hammar-Klose, 1999, 2000a, and 2000b). This approach best describes and highlights the vulnerability specific to each park.

\section{Results}

The calculated CVI values for Gateway range from 5.77 to 35.36 . The mean CVI value is 14.80 ; the mode is 21.91 and the median 10.95. The standard deviation is 7.48. The 25th, 50th, and 75th percentiles are 8.5, 11.0, and 22.0, respectively.

Figure 7 shows a map of the CVI (vulnerability ranges) for Gateway National Recreation Area. The CVI scores are divided into low, moderate, high, and very high-vulnerability categories based on the quartile ranges. CVI values below 8.50 are assigned to the low vulnerability category. Values from 8.5-11.0 are considered moderate vulnerability. High-vulnerability values lie between 11.51 and 22.0. CVI values above 22.0 are classified as very high 
vulnerability. Figure 8 shows a histogram of the percentage of Gateway shoreline in each vulnerability category. Nearly $45 \mathrm{~km}$ (120 miles) of shoreline is evaluated along the Gateway NRA. Of this total, 24 percent of the mapped shoreline is classified as being at very high vulnerability due to future sea-level rise, all of which occurs at Sandy Hook, mostly on the seaward side. Another 24 percent is classified as high vulnerability, 28 percent as moderate vulnerability, and 24 percent as low vulnerability, almost all of which occurs along the Staten Island Unit from Ft. Wadsworth to Miller Field.

\section{Discussion}

The data within the CVI show variability at different spatial scales (Figure 7). The ranked values for the physical process variables generally vary less over the extent of the shoreline than the geologic variables. The value of the relative sea-level rise variable changes across the Hudson Shelf Valley from very high in NJ to moderate in NY. The significant wave height variable changes from very low to very high as a result of varying shoreline orientations, but the tidal range is ranked as very high vulnerability for all of Gateway.

The geologic variables show higher resolution variability and thus have the most influence on the CVI value and ranges (Figure 7). Geomorphology in the park includes barrier spit shoreline and artificial fill ranked as very high vulnerability. Areas of glacial outwash were ranked as high vulnerability, and the terminal moraine near Ft. Wadsworth was ranked as moderate vulnerability. Vulnerability assessment based on historical shoreline change trends varies from very low to very high (Figure 6A-E). Regional coastal slope varies from very low to high vulnerability.

The influential variables in the CVI are geomorphology, shoreline change, regional coastal slope, rate of sea-level rise, and significant wave height; therefore they may be considered the dominant factors controlling how Gateway will evolve as sea level rises. The sea level rise variable and wave height variable control regional differences in vulnerability, while the geologic variables resolve the coastal vulnerability within the park units.

Because of development and high economic value of property along the coast of Rockaway Beach and towns south of Sandy Hook such as Sea Bright, concern about erosion, storm-surge breaching of the barriers, future sea level rise, and mainland flooding, planning by Federal and State agencies may be required to address these issues. Alternatives such as large-scale nourishment of the beach and dunes along Rockaway Beach and Sea Bright could alter the CVI results presented here and mitigate sea-level rise effects.

\section{Conclusions}

The coastal vulnerability index (CVI) provides insight into the relative potential of coastal change due to future sea-level rise. The maps and data presented here can be viewed in at least two ways:

1) as an indicator of where physical changes are most likely to occur as sea-level rises; and

2) as a planning tool for the Gateway National Recreation Area.

As ranked in this study, geomorphology, shoreline change, coastal slope, rate of relative sea-level rise, and significant wave height are the most important variables in determining the CVI for Gateway. Tide range does not contribute to the spatial variability in the CVI within Gateway.

Gateway preserves a dynamic natural environment, which must be understood in order to be managed properly. The CVI is one way that a park can assess objectively the natural factors that contribute to the evolution of the coastal zone, and thus how the park may evolve in the future. 


\section{References}

Douglas, B.C., 1997, Global sea rise, a redetermination: Surveys in Geophysics, v. 18, p. $279-292$.

Gornitz, V., and White, T.W., 1992, A coastal hazards database for the U.S. West Coast: ORNL/CDIAC-81, NDP-043C, Oak Ridge National Laboratory, Oak Ridge, Tenn.

Gornitz, V.M., Daniels, R.C., White, T.W., and Birdwell, K.R., 1994, The development of a coastal vulnerability assessment database, vulnerability to sea-level rise in the U.S. southeast: Journal of Coastal Research, Special Issue No. 12, p. 327-338.

Gornitz, V.M., Couch, S., Hartig, E., 2001, Impacts of sea level rise in New York City metropolitan area: Global and Planetary Change, v. 32, no. 1, p. 61-88.

Hammar-Klose, E.S., and Thieler, E.R., 2001, Coastal vulnerability to sea-level rise; A preliminary database for the U.S. Atlantic, Pacific, and Gulf of Mexico coasts: U.S. Geological Survey, Digital Data Series, DDS-68, CD-ROM. (Available online at: http://pubs.usgs.gov/dds/dds68//

Hartig, E.K., Kolker, A., Fallon, D., and Mushacke, F., 2001, Wetlands, in Rosenzweig, C., and Solecki, W., eds., Climate Change and a Global City; The Potential Consequences of Climate Variability and Change--Metro East Coast: Report for the U.S. Global Change Program, National Assessment of the Potential Consequences of Climate Variability and Change for the United States, Columbia Earth Institute, Columbia University, New York, N.Y., p. 67-86.

Hartig, E.K., Gornitz, V.M., Kolker, A, Mushacke, F., and Fallon, D., 2002, Anthropogenic and climate change impacts on salt marshes of Jamaica Bay, New York City: Wetlands, v. 22, no. 1, p. 71-89.

Hubertz, J.M., Thompson, E.F., and Wang, H.V., 1996, Wave Information Studies of U.S. coastlines, Annotated bibliography on coastal and ocean data assimilation: WIS Report 36, U.S. Army Engineer Waterways Experiment Station, Vicksburg, 31 p.

IPCC (Intergovernmental Panel on Climate Change), 2001, Climate Change 2001, in Houghton, J.T., Ding, Y., Griggs, D.J., Noguer, M., van der Linden, P.J., and Xiaosu, D., eds., The Scientific Basis; Contribution of Working Group I to the Third Assessment Report of the Intergovernmental Panel on Climate Change (IPCC): Cambridge, University Press, U.K., 944 p. (Also available at http://www.ipcc.ch/)

National Research Council, 1990, Managing Coastal Erosion, Washington: National Academy Press, $163 \mathrm{p}$.

National Research Council, 1995, Beach Nourishment and Protection, Washington: National Academy Press, $334 \mathrm{p}$.

Pilkey, O.H., and Davis, T.W., 1987, An analysis of coastal recession models, North Carolina coast, in Nummedal, D., Pilkey, O.H., and Howard, J.D., eds., Sea-level Fluctuation and Coastal Evolution: SEPM (Society for Sedimentary Geology) Special Publications No. 41, Tulsa, Okla., p. 59-68.

Shaw, J., Taylor, R.B., Forbes, D.L., Ruz, M.H., and Solomon, S., 1998, Sensitivity of the Canadian Coast to Sea-Level Rise: Geological Survey of Canada Bulletin 505, $114 \mathrm{p}$.

Soren, J., 1988, Geologic and geohydrologic reconnaissance of Staten Island, New York: U.S. Geological Survey, WaterResources Investigations Report 87-4048, scale 1:41700.

Thieler, E.R., and Hammar-Klose, E.S., 1999, National assessment of coastal vulnerability to sea-level rise, U.S. Atlantic Coast: U.S. Geological Survey Open-File Report 99-593, 1 sheet. (Available online at: http://pubs.usgs.gov/of/of99-593/.)

Thieler, E.R., and Hammar-Klose, E.S., 2000a, National assessment of coastal vulnerability to sea-level rise, U.S. Pacific Coast: U.S. Geological Survey Open-File Report 00-178, 1 sheet. (Available online at: http://pubs.usgs.gov/of/of00-178/.)

Thieler, E.R., and Hammar-Klose, E.S., 2000b, National assessment of coastal vulnerability to sea-level rise, U.S. Gulf of Mexico Coast: U.S. Geological Survey Open-File Report 00-179, 1 sheet. (Available online at: http://pubs.usgs.gov/of/of00-179/.)

Zervas, C., 2001, Sea Level Variations of the United States 1854-1999: NOAA Technical Report NOS CO-OPS 36, 201 p. 


\section{List of Figures}

Figure 1. Location of Gateway National Recreation Area in New York and New Jersey. For detailed maps of each Unit within Gateway National Recreation visit Web site: http://www.nps.gov/gate/pphtml/maps.html

Figure 2. Surficial geology map for Staten Island (based on data from the NY Geological Survey) (Soren, 1988).

Figure 3. Shoreline grid for Gateway National Recreation Area.

Figure 4. Photos of the very high vulnerability barrier island geomorphology within Breezy Point District and Sandy Hook Unit of Gateway National Recreation Area. A) Photos from the Breezy Point District at Jacob Riis Park show the beach with a series of groins fronting the bathhouse (left) and storm overwash and erosion along the base of the boardwalk (right). B) The Atlantic Ocean shoreline of Sandy Hook looking north from Gunnison Beach (left) and the Sandy Hook Bay shoreline at the entrance to Spermaceti Cove (right).

Figure 5. Photos of the different geomorphology types within the Staten Island Unit of Gateway NRA. A) A view of Fort Wadsworth and the narrows from the terminal moraine (moderate vulnerability) (NPS photo). B) The shoreline at Miller Field is composed of outwash material (high vulnerability). C) Great Kills Park is built on artificial fill (very high vulnerability.

Figure 6. Historic shoreline position index map for A) Breezy Point District from Jacob Riis Park to Breezy Point Jetty, B) Staten Island Unit from Ft. Wadsworth to Miller Field, C) Staten Island Unit from Miller Field to Great Kill Park, D) Northern Sandy Hook Unit, and E) Southern Sandy Hook Unit. Click on box for larger image.

Figure 6A. Breezy Point District from Jacob Riis Park to Breezy Point Jetty.

Figure 6B. Staten Island Unit from Ft. Wadsworth to Miller Field.

Figure 6C. Staten Island Unit from Miller Field to Great Kill Park.

Figure 6D. Northern Sandy Hook Unit.

Figure 6E. Southern Sandy Hook Unit.

Figure 7. Relative Coastal Vulnerability for Gateway National Recreation Area. The innermost color bar is the relative coastal vulnerability index (CVI). The remaining color bars are separated into the geologic variables (1-3) and physical process variables $(4-6)$. The very high vulnerability shoreline is generally located along Sandy Hook where shoreline change rates and wave heights are highest. High vulnerability shoreline is along the eastern end of the Breezy Point District. Moderate and low vulnerability shoreline is concentrated along the Staten Island Unit.

Figure 8. Percentage of Gateway shoreline in each vulnerability category. 


\section{List of Tables}

Table 1. Ranges for Vulnerability Ranking of Variables on the Atlantic/Caribbean Coast.

Table 2. Sources of Data 


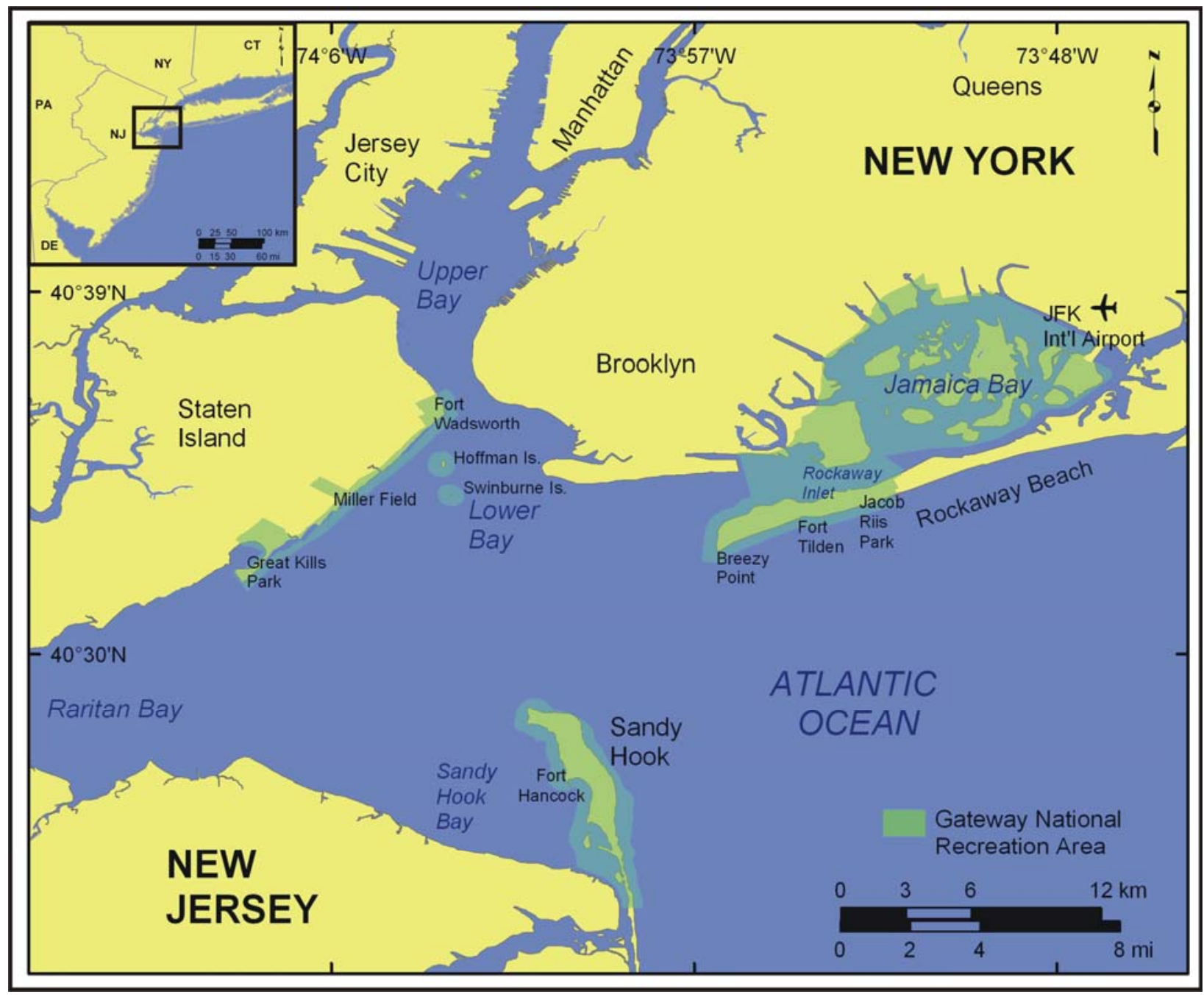

Figure 1. Location of Gateway National Recreation Area in New York and New Jersey. For detailed maps of each Unit within Gateway National Recreation visit Web site: http://www.nps.gov/gate/pphtml/maps.html 


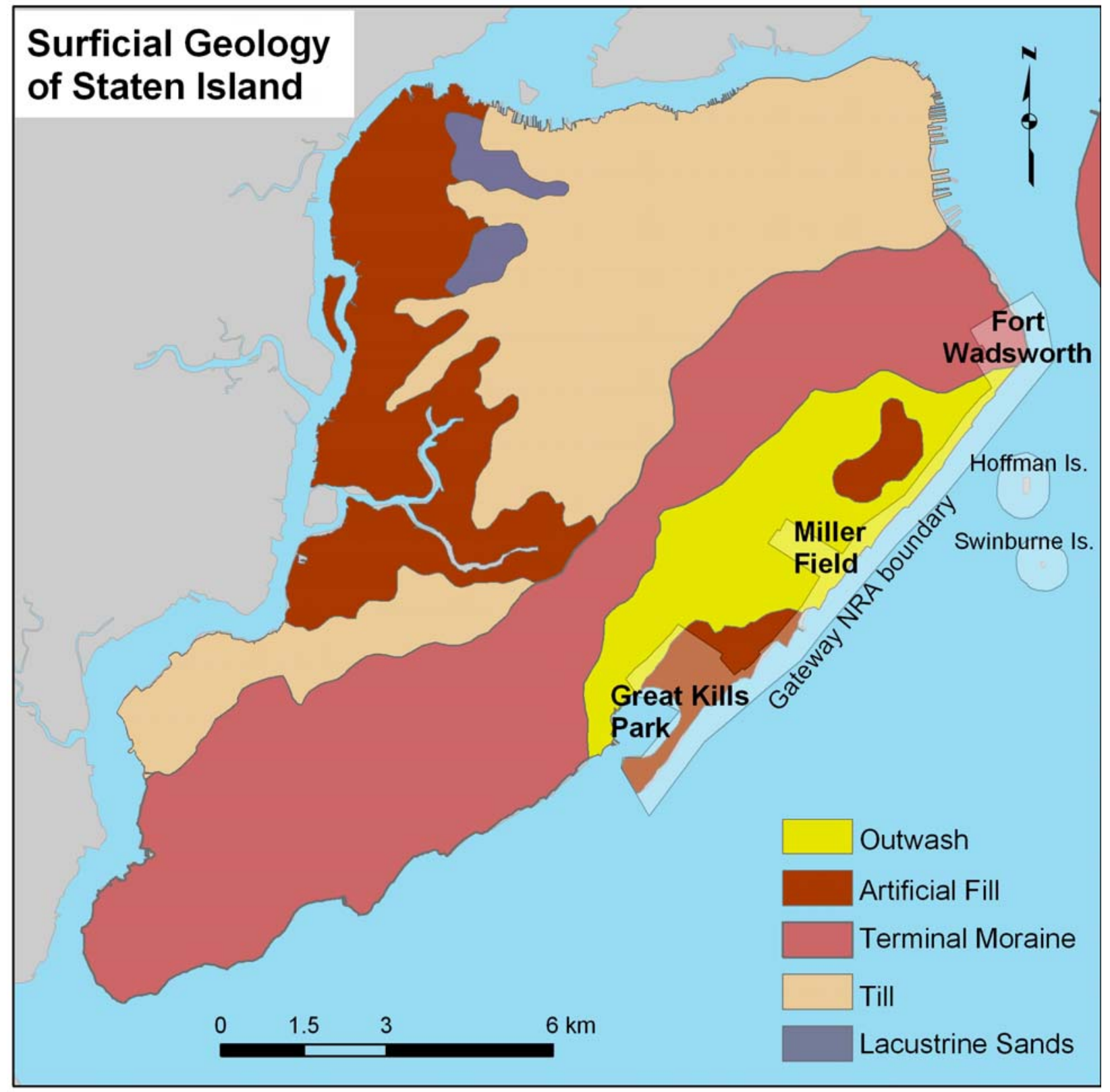

Figure 2. Surficial geology map for Staten Island (based on data from the NY Geological Survey) (Soren, 1988). 


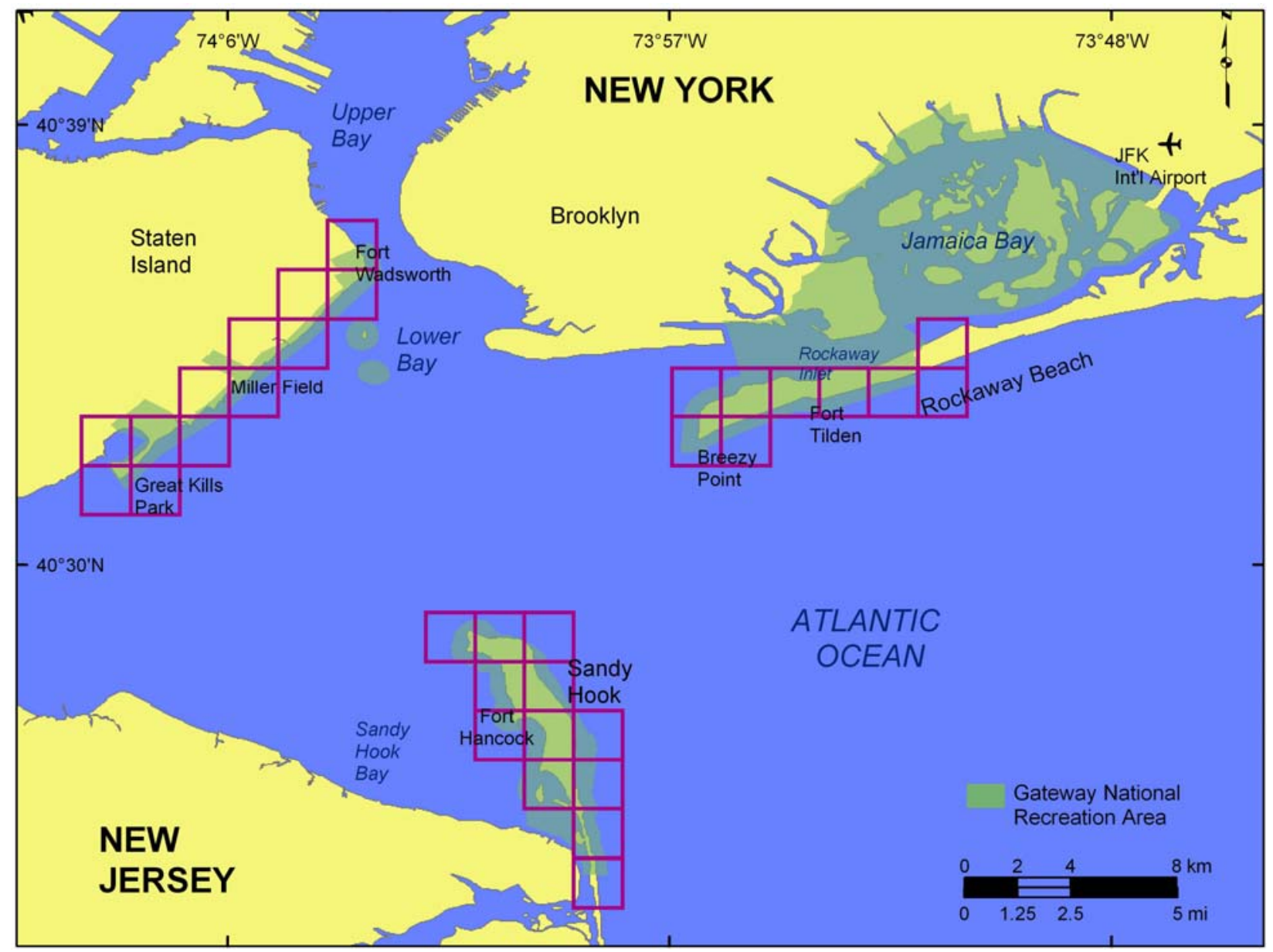

Figure 3. Shoreline grid for Gateway National Recreation Area. 

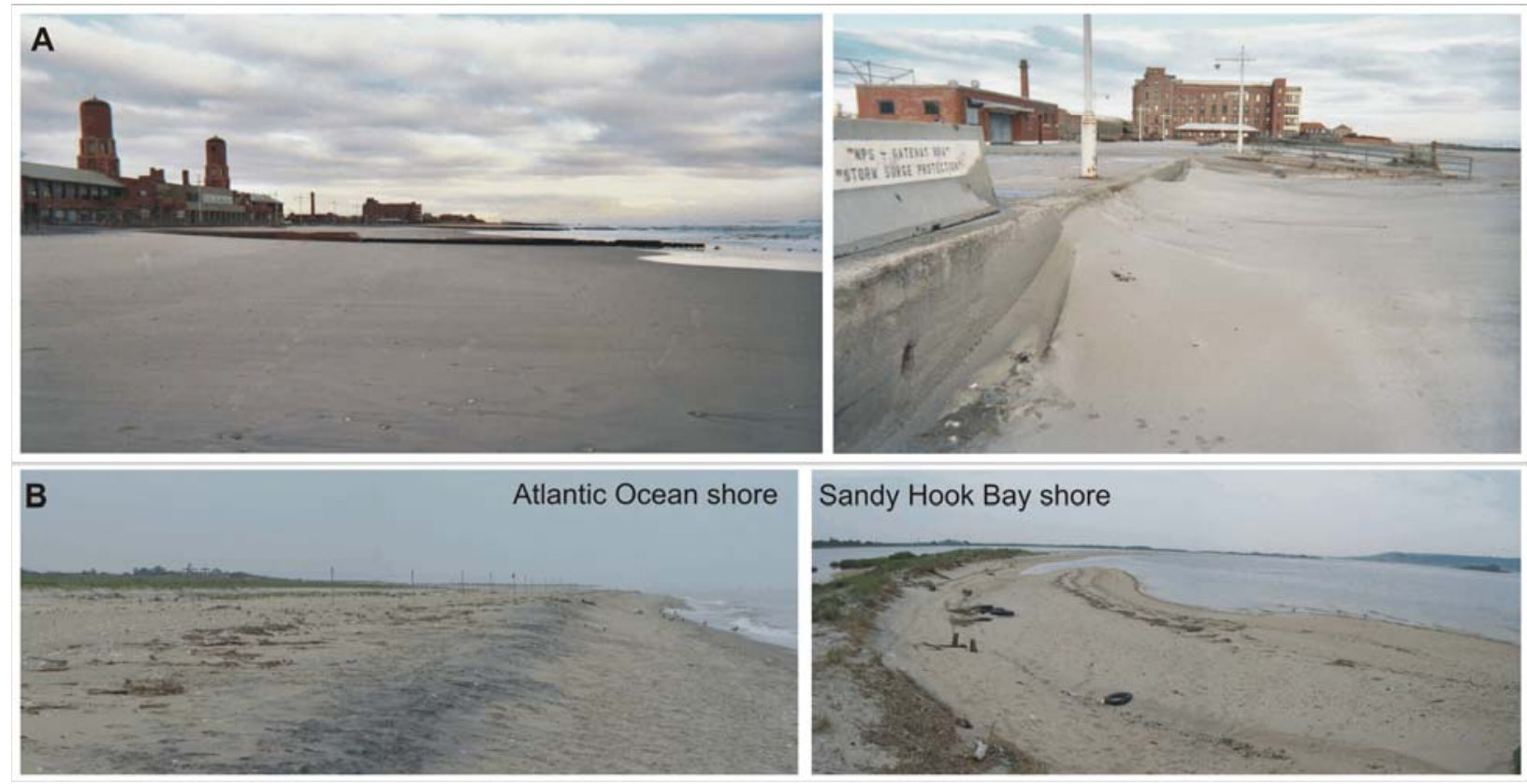

Figure 4. Photos of the very high vulnerability barrier island geomorphology within Breezy Point District and Sandy Hook Unit of Gateway National Recreation Area. A) Photos from the Breezy Point District at Jacob Riis Park show the beach with a series of groins fronting the bathhouse (left) and storm overwash and erosion along the base of the boardwalk (right). B) The Atlantic Ocean shoreline of Sandy Hook looking north from Gunnison Beach (left) and the Sandy Hook Bay shoreline at the entrance to Spermaceti Cove (right). 

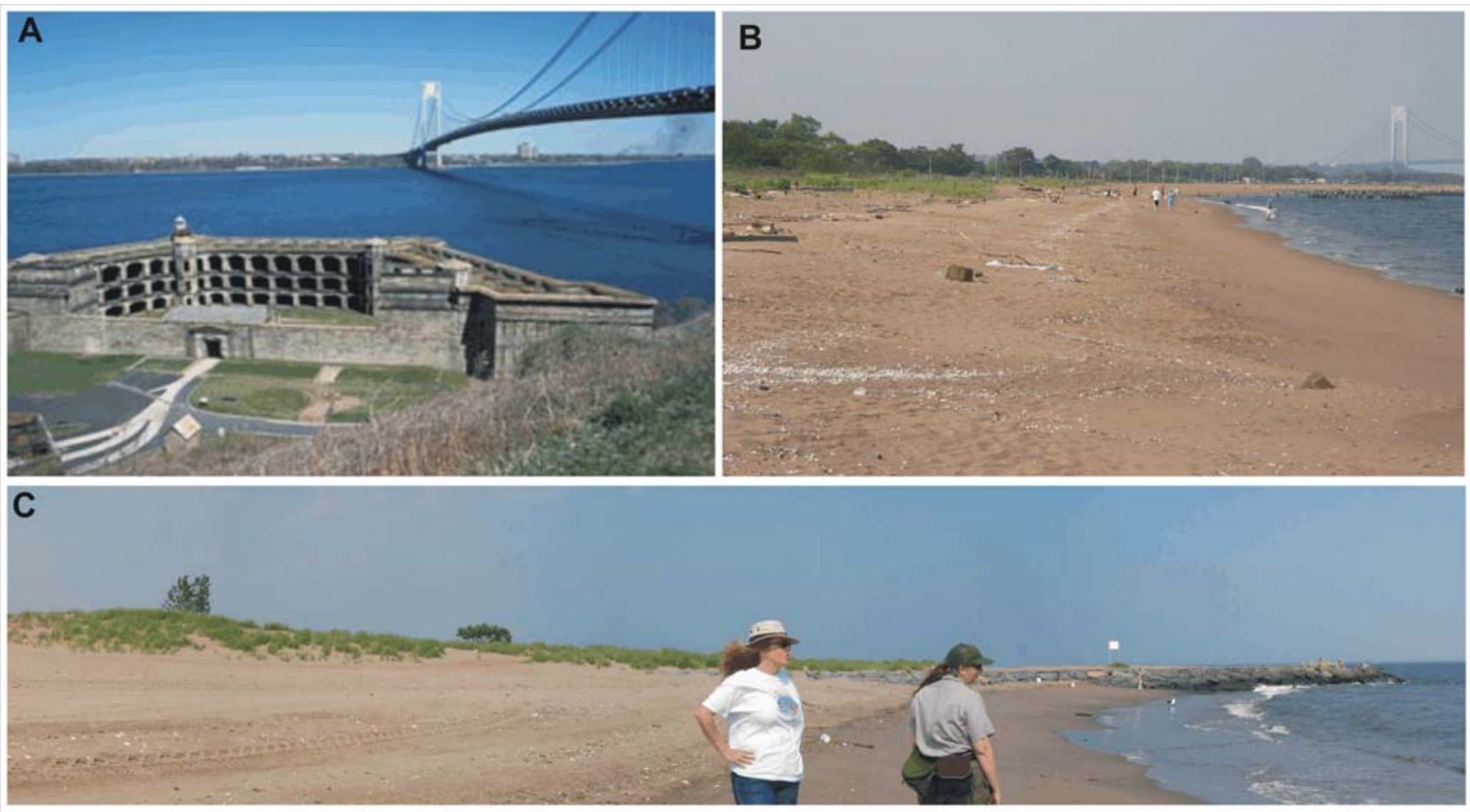

Figure 5. Photos of the different geomorphology types within the Staten Island Unit of Gateway NRA. A) A view of Fort Wadsworth and the narrows from the terminal moraine (moderate vulnerability) (NPS photo). B) The shoreline at Miller Field is composed of outwash material (high vulnerability). C) Great Kills Park is built on artificial fill (very high vulnerability. 


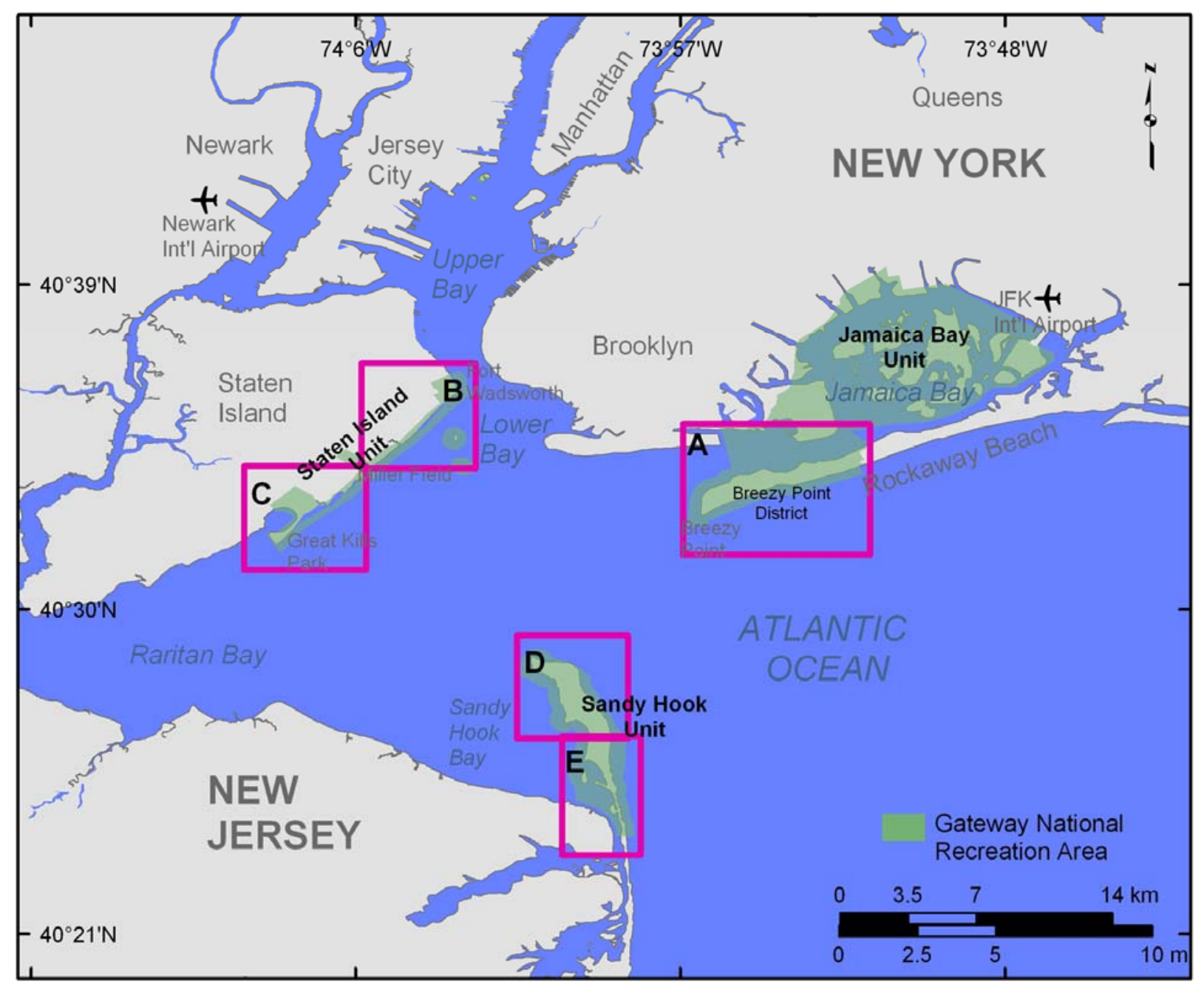

Figure 6. Historic shoreline position index map for A) Breezy Point District from Jacob Riis Park to Breezy Point Jetty, B) Staten Island Unit from Ft. Wadsworth to Miller Field, C) Staten Island Unit from Miller Field to Great Kill Park, D) Northern Sandy Hook Unit, and E) Southern Sandy Hook Unit. Click on box for larger image. 


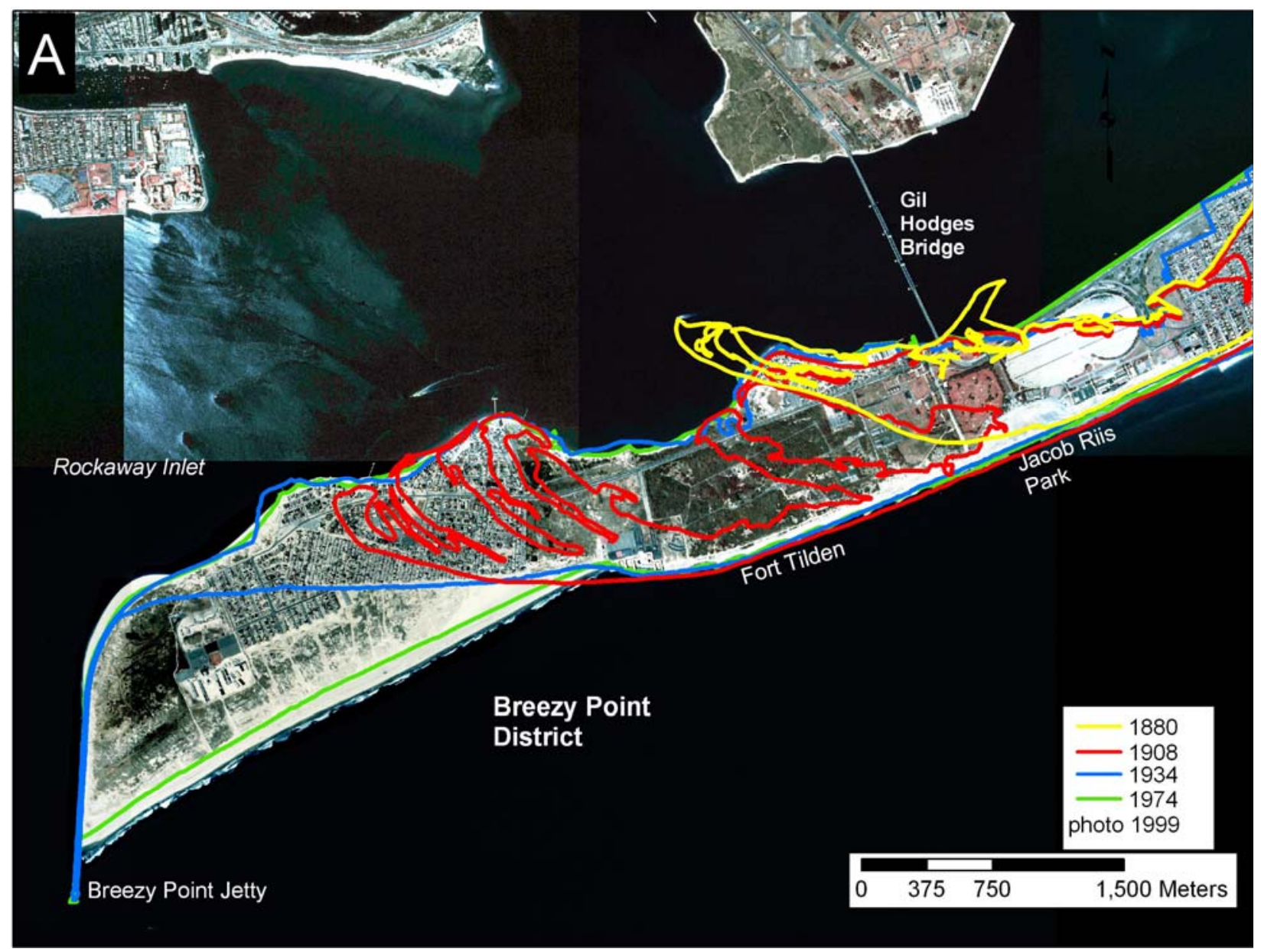

Figure 6A. Breezy Point District from Jacob Riis Park to Breezy Point Jetty. 


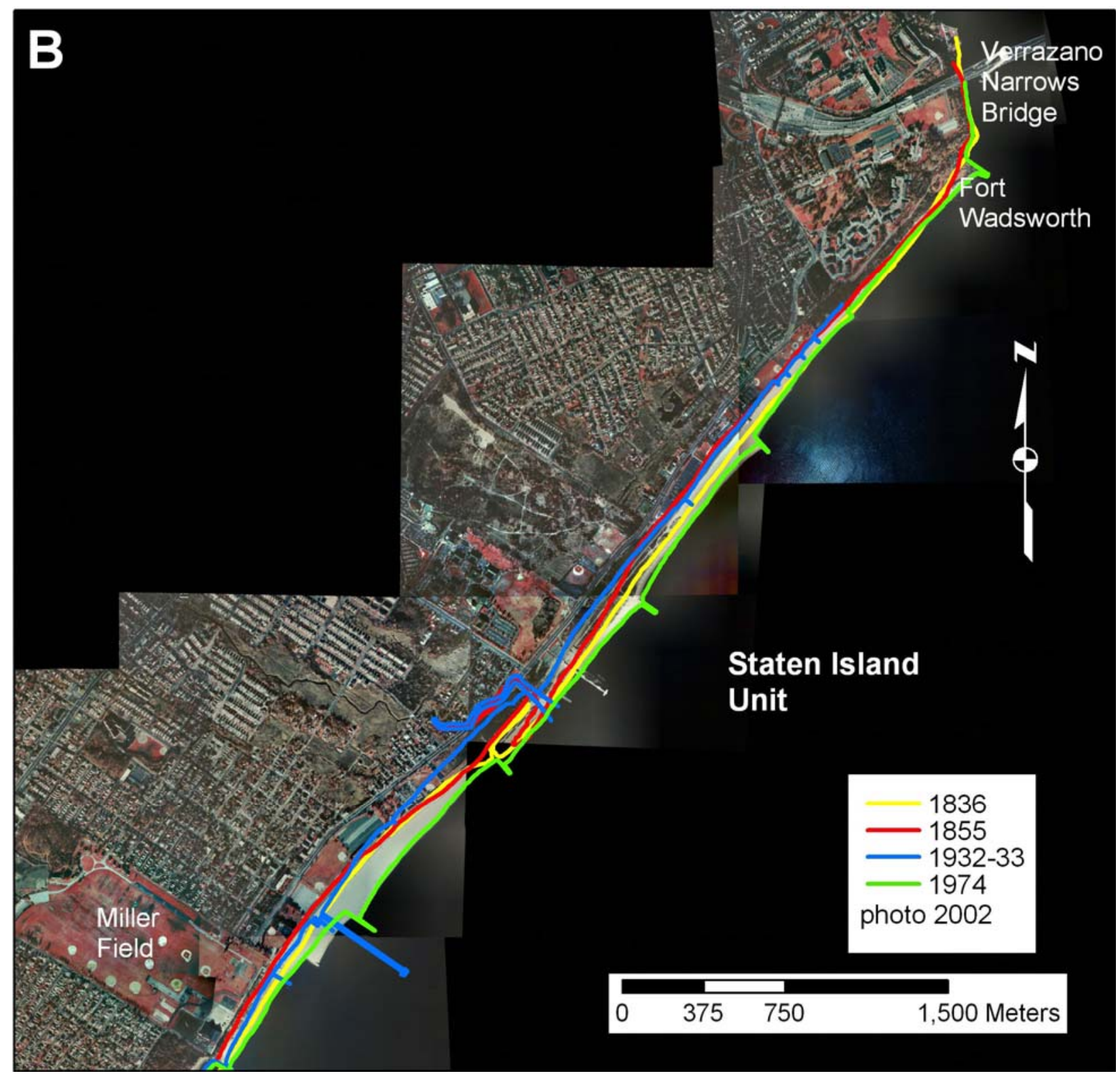

Figure 6B. Staten Island Unit from Ft. Wadsworth to Miller Field. 


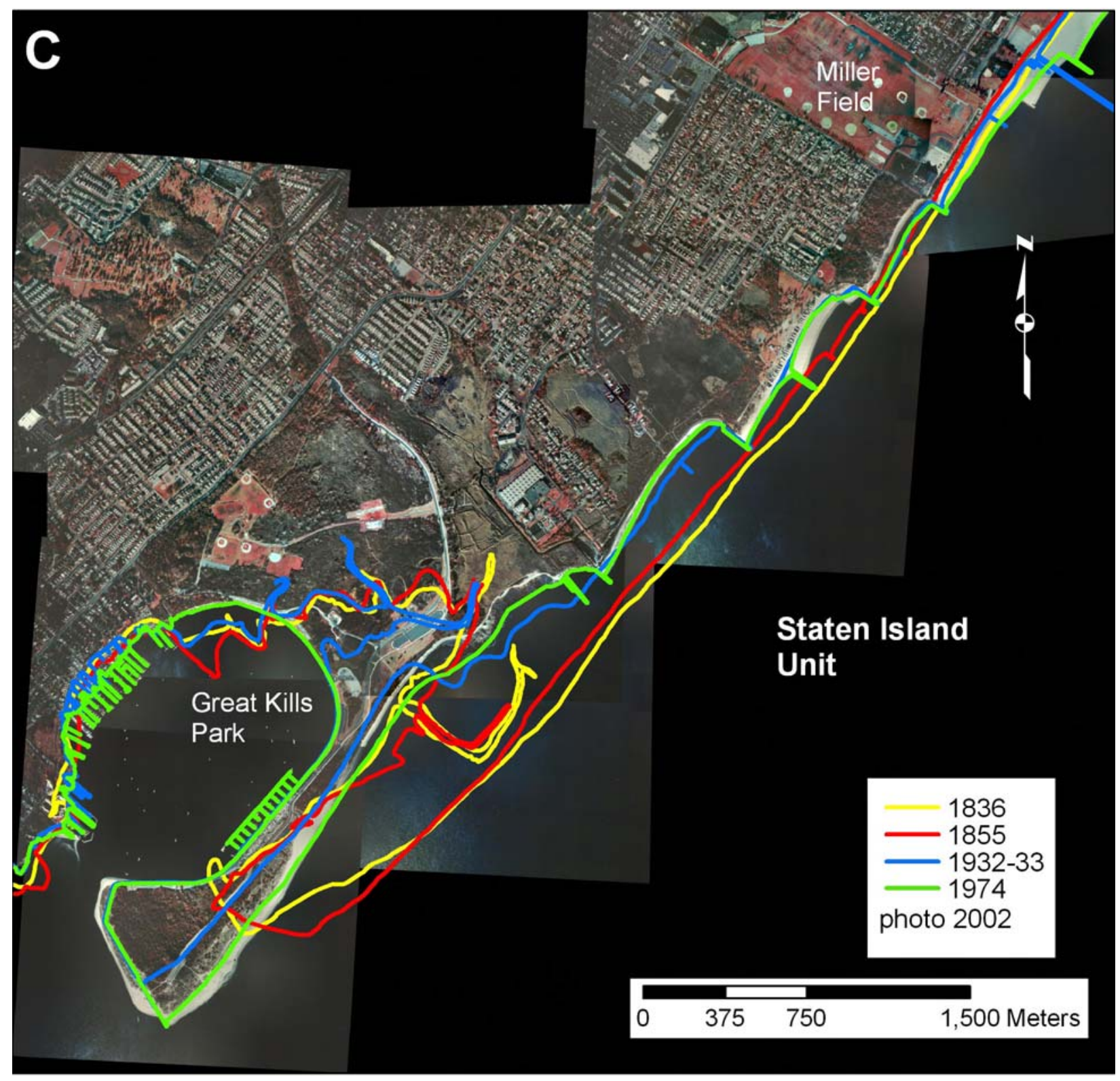

Figure 6C. Staten Island Unit from Miller Field to Great Kill Park. 


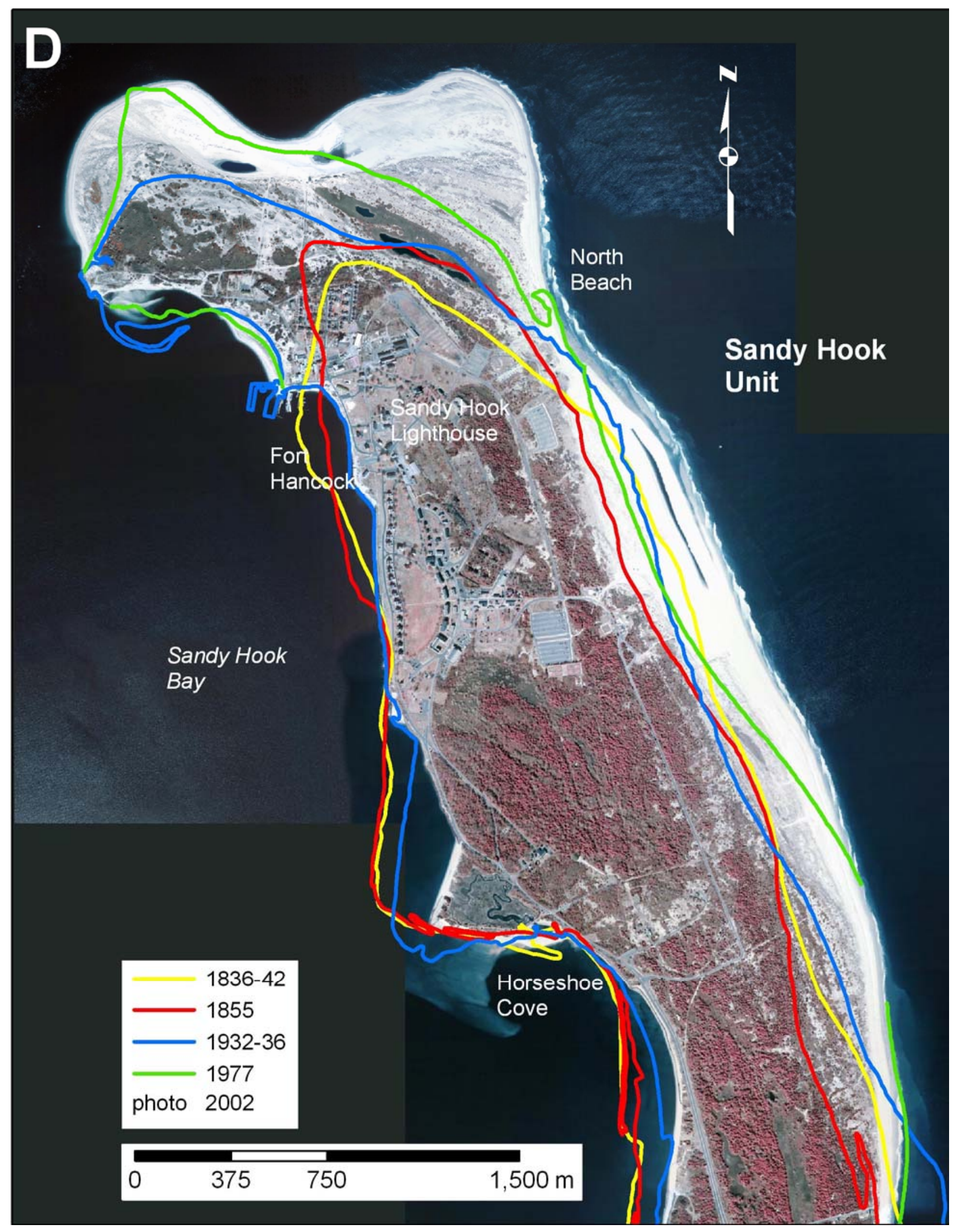

Figure 6D. Northern Sandy Hook Unit. 


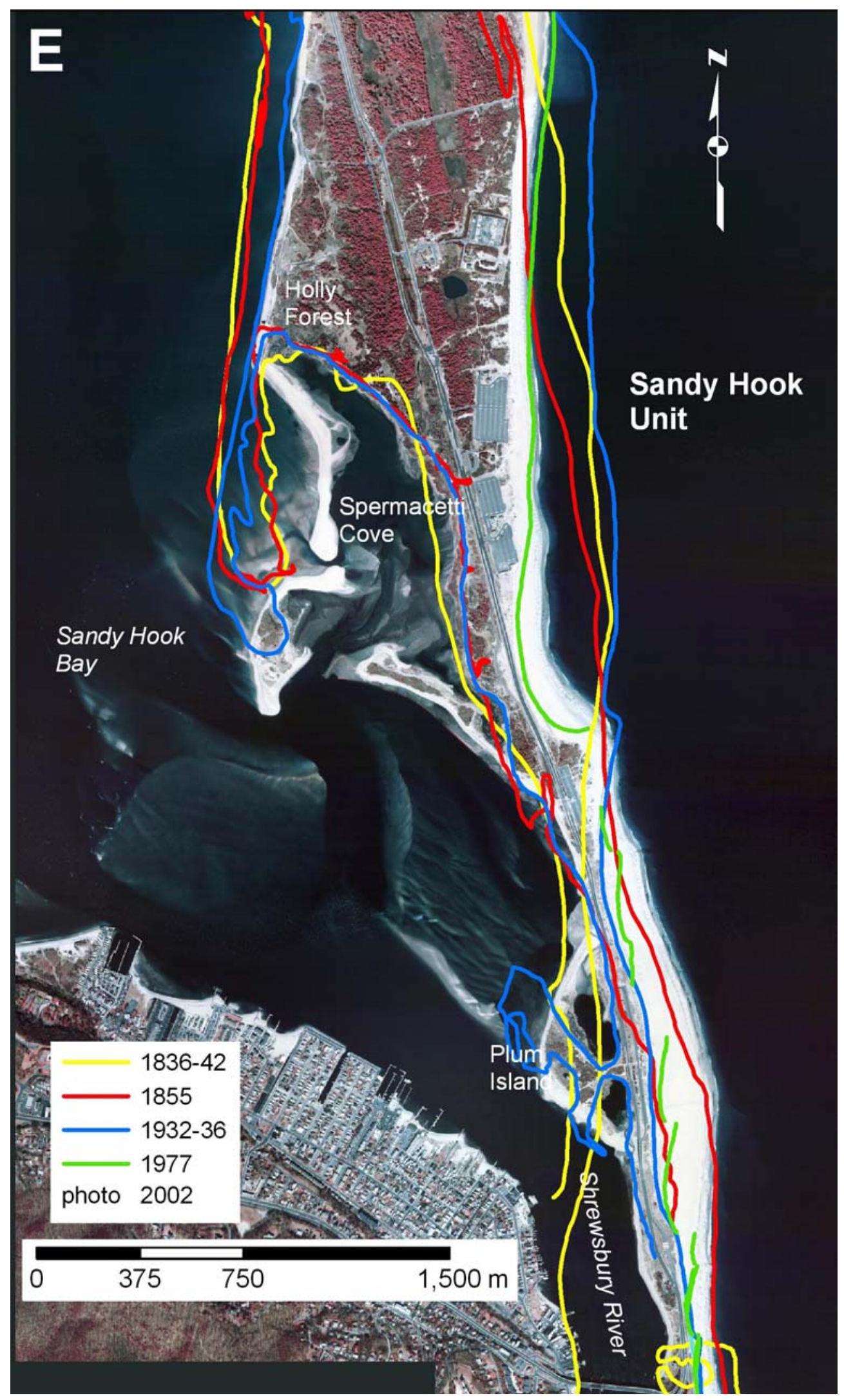

Figure 6E. Southern Sandy Hook Unit. 


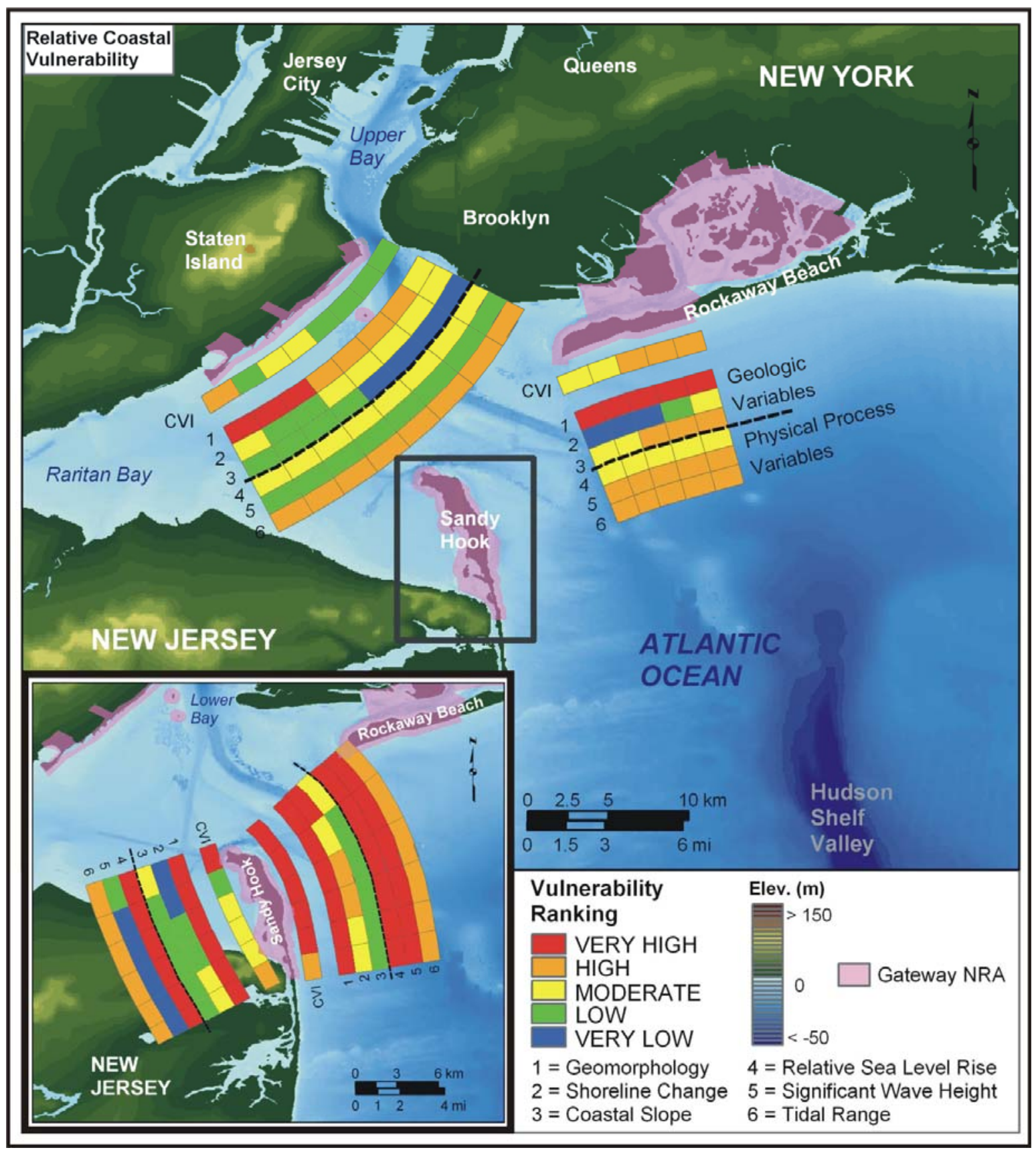

Figure 7. Relative Coastal Vulnerability for Gateway National Recreation Area. The innermost color bar is the relative coastal vulnerability index (CVI). The remaining color bars are separated into the geologic variables (1-3) and physical process variables (4 - 6). The very high vulnerability shoreline is generally located along Sandy Hook where shoreline change rates and wave heights are highest. High vulnerability shoreline is along the eastern end of the Breezy Point District. Moderate and low vulnerability shoreline is concentrated along the Staten Island Unit. 


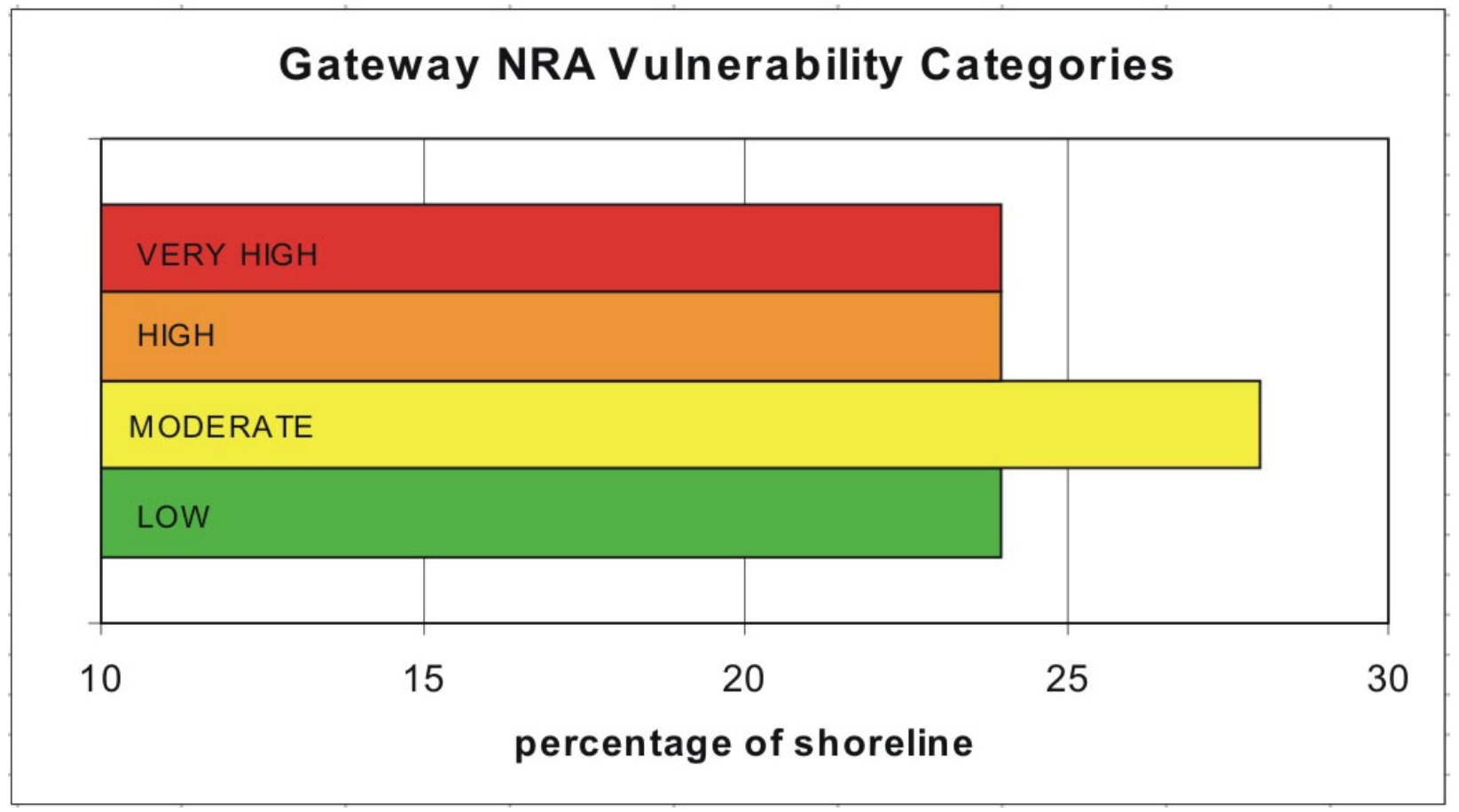

Figure 8. Percentage of Gateway shoreline in each vulnerability category. 
Table 1. Ranges for Vulnerability Ranking of Variables on the Atlantic Coast.

\begin{tabular}{|c|c|c|c|c|c|}
\hline Variables & $\begin{array}{c}\text { Very Low } \\
1\end{array}$ & $\begin{array}{l}\text { Low } \\
2\end{array}$ & $\begin{array}{c}\text { Moderate } \\
\quad 3\end{array}$ & $\begin{array}{l}\text { High } \\
4\end{array}$ & $\begin{array}{l}\text { Very High } \\
5\end{array}$ \\
\hline GEOMORPHOLOGY & $\begin{array}{l}\text { Rocky } \\
\text { cliffed } \\
\text { coasts, } \\
\text { Fjords }\end{array}$ & $\begin{array}{l}\text { Medium } \\
\text { cliffs, } \\
\text { Indented } \\
\text { coasts }\end{array}$ & $\begin{array}{l}\text { Low cliffs, } \\
\text { Glacial drift, } \\
\text { Alluvial } \\
\text { plains }\end{array}$ & $\begin{array}{c}\text { Cobble } \\
\text { Beaches, } \\
\text { Estuary, Lagoon }\end{array}$ & $\begin{array}{c}\text { Barrier beaches, Sand beaches, } \\
\text { Salt marsh, Mud flats, Deltas, } \\
\text { Mangrove, Coral reefs }\end{array}$ \\
\hline $\begin{array}{l}\text { SHORELINE EROSION/ } \\
\text { ACCRETION (m/yr) }\end{array}$ & $>2.0$ & $1.0-2.0$ & $-1.0-1.0$ & $-2.0--1.0$ & $<-2.0$ \\
\hline COASTAL SLOPE (\%) & $>1.20$ & $1.20-0.90$ & $0.90-0.60$ & $0.60-0.30$ & $<0.30$ \\
\hline $\begin{array}{l}\text { RELATIVE SEA-LEVEL CHANGE } \\
\text { (mm/yr) }\end{array}$ & $<1.8$ & $1.8-2.5$ & $2.5-3.0$ & $3.0-3.4$ & $>3.4$ \\
\hline MEAN WAVE HEIGHT (m) & $<0.55$ & $0.55-0.85$ & $0.86-1.05$ & $1.06-1.25$ & $>1.25$ \\
\hline MEAN TIDE RANGE (m) & $>6.0$ & $4.0-6.0$ & $2.0-4.0$ & $1.0-2.0$ & $<1.0$ \\
\hline
\end{tabular}




\begin{tabular}{|c|c|c|}
\hline Variables & Source & $\begin{array}{c}\text { URL } \\
\text { (Not all sources are downloadable) }\end{array}$ \\
\hline GEOMORPHOLOGY & $\begin{array}{l}2002 \text { Orthophotos from the } \\
\text { New Jersey Image } \\
\text { Warehouse 1994-2002 } \\
\text { Orthophotos from the New } \\
\text { York State Statewide } \\
\text { Orthoimagery Program }\end{array}$ & $\begin{array}{l}\text { http://njgin.nj.gov/OIT IW/index.jsp } \\
\text { http://www.nysgis.state.ny.us/gateway/orthoprogram/ }\end{array}$ \\
\hline $\begin{array}{c}\text { SHORELINE } \\
\text { EROSION/ACCRETION (m/yr) }\end{array}$ & $\begin{array}{l}\text { Historical Shorelines for New } \\
\text { York and New Jersey coast } \\
\text { (1866 -2001) from the US } \\
\text { Geological Survey, NY State } \\
\text { Department of State, and } \\
\text { New Jersey Department of } \\
\text { Environmental Protection }\end{array}$ & $\begin{array}{l}\text { http://coastal.er.usgs.gov/national-assessment/ } \\
\text { https://njgin.state.nj.us/ }\end{array}$ \\
\hline COASTAL SLOPE (\%) & $\begin{array}{l}\text { NGDC Coastal Relief Model } \\
\text { Vol } 01\end{array}$ & http://www.ngdc.noaa.gov/mgg/coastal/coastal.html \\
\hline $\begin{array}{l}\text { RELATIVE SEA-LEVEL CHANGE } \\
(\mathrm{mm} / \mathrm{yr})\end{array}$ & $\begin{array}{l}\text { NOAA Technical Report NOS } \\
\text { CO-OPS } 36 \text { SEA LEVEL } \\
\text { VARIATIONS OF THE UNITED } \\
\text { STATES 1854-1999 (Zervas, } \\
\text { 2001) }\end{array}$ & http://www.co-ops.nos.noaa.gov/publications/techrpt36doc.pdf \\
\hline MEAN WAVE HEIGHT (m) & $\begin{array}{l}\text { North Atlantic Region WIS } \\
\text { Data (Phase II) and NOAA } \\
\text { National Data Buoy Center }\end{array}$ & $\begin{array}{l}\text { http://frf.usace.army.mil/wis/ } \\
\text { http://seaboard.ndbc.noaa.gov/ }\end{array}$ \\
\hline MEAN TIDE RANGE (m) & $\begin{array}{l}\text { NOAA/NOS CO-OPS Historical } \\
\text { Water Level Station Index }\end{array}$ & http://www.co-ops.nos.noaa.gov/usmap.html \\
\hline
\end{tabular}

